\title{
Creativity is Always a Social Process*
}

\author{
Romina Elisondo \\ Universidad Nacional de Río Cuarto, Argentina \\ E-mail address: relisondo@gmail.com
}

\section{ARTICLE INFO}

\section{Keywords:}

Everyday Creativity

Big C Creativity

Leisure

Psychology of Creativity

Context

Interactions

\section{Article history:}

Received 12 March 2016

Received in revised form 18 July 2016

Accepted 9 September 2016

ISSN: 2354-0036

DOI: $10.1515 /$ ctra-2016-0013

\section{A B S TR A C T}

\begin{abstract}
The article explores the social essence of creativity. Two studies where interactions with others shape the development of creative processes are presented; first, theoretical perspectives on creativity as social process are discussed. The first study analyzes social aspects of creative processes developed during leisure activities. Men and women $(\mathrm{N}=150)$ living in Córdoba (Argentina) were interviewed in the research. The second study is a form of biographical research. The sample includes 22 Argentine personalities prominent in the scientific and artistic fields. As a main result, in the two studies we observed that links with family, teachers, peers, colleagues, mentors, tutors and disciples shape the possibilities of developing everyday creativity as well as Big-C creativity. Finally, considerations and suggestions for future research on creativity as a social process are presented. Creativity emerges from dialogues, interactions and practices with others. It is not a solitary process: it involves languages, knowledge and actions that are socially constructed.
\end{abstract}

\section{INTRODUCTION}

Creative processes always depend on direct or indirect interaction with other people. Creativity does not exist in a vacuum. Even in cases where the person develops creative processes in solitude, he or she always does so on the basis of languages, knowledge, procedures and expectancies that are socially constructed. In this article, two studies with convergent results are presented: their main finding is that creativity is always otherdependent.

In this paper, we argue for the theoretical and practical relevance of a social perspective on creativity and show results from research which account for this approach. First, theoretical perspectives on creativity as a social process are presented. Then, two research studies are discussed. In the first study we analyze social aspects in creative

\footnotetext{
"The study was conducted under the PIP (2014-2016) project subsidized by the National Council of Scientific and Technical Research of Argentina (CONICET) and the PICT 2615/2013 project subsidized by the Agency for Scientific and Technological Promotion of Argentina
} 
processes developed by ordinary people during their free time/leisure activities. For this purpose, 150 adult participants (in the age range from 18 to 85 ) living in the province of Córdoba (Argentina) were interviewed. The second study represents biographical research on creative processes conducted with 22 renowned Argentineans, distinguished in various scientific and artistic fields. In conclusion, final considerations and future lines of research and investigation are proposed.

\section{THEORETICAL PERSPECTIVES ON CREATIVITY BEYOND ALONENESS AND CAPABILITIES}

Common stereotypes tend to link creativity with solitary, spontaneous, casual and sudden processes. However, developments in creativity research reveal that these stereotypes have little to do with what really happens during creative processes. Creators develop numerous efforts to achieve creative outcomes and many working hours are spent between ideas and their creative products. In addition, creative ideas and products always depend, in a certain way, on interaction with other people and culturally constructed and reconstructed knowledge and procedures.

In the field of creativity, the role of the others was not considered at the beginning of systematic research. Studies on the creative capacities of ordinary people as well as biographical research on creativity have focused on the analysis of subjective variables disregarding any social and relational aspects. In many cases social aspects have been considered, but in isolation, or only as external influences (Hennessey \& Amabile, 2010).

In adopting a sociocultural perspective, it is our interest to understand creativity in terms of processes of appropriation and internalization of different knowledge, languages and interactions with others. The social is not outside the subject; on the contrary, it constructs and reconstructs him/her permanently.

The basic premise of this model is that, when people generate new ideas as part of their on-going creative action, they do so by alternating between and integrating perspectives and these perspectives are fundamentally linked to social positions and practices. In other words, the cognitive processes involved in divergent thinking are intrinsically social as they both emerge out of social experience and reflect its polyphonic and dialogical character. This last feature is well documented in dialogism and dialogical self theory (Hermans, 2001), another strand of literature that strongly advocates for a social reformulation of seemingly individual, intra-psychological processes (Glăveanu, 2015a, p. 113).

In agreement with Glăveanu (2010), we believe in the need for developing sociocultural approaches that take into account the relationships between people, communities and cultural artifacts which are generated in creative processes. The author proposes a new paradigm that transcends the perspectives of I (research on everyday 
creativity), HE (research on creativity that is socially acknowledged) and WE (approaches which consider the incidence of social and systematic variables on creativity), and studies creativity within the frame of the interrelations between four elements: the creative subject, community, existent cultural artifacts and new products being created. Recently, Hoff (2015) has argued for the need to incorporate the perspectives of SHE, YOU and THEY, emphasizing motivational and emotional aspects, and the interaction between subject and other. The author proposed a definition of creativity in terms of a collaborative, generative and novel way of experimenting with reality.

Saywer (2006) stressed the need for interdisciplinary studies of creativity that integrate individual, social, cultural and historical approaches. Creative processes depend not only on individuals; to consider collaborative work with others, in social, cultural and historical contexts is indispensable.

But creativity research is still in its infancy (...) For a complex phenomenon like creativity, a complete understanding requires us to develop explanations at individual, social, and cultural levels. We need to understand relationships between individuals and contexts: how conventions emerge from groups of people, and how people are influenced by the conventions of a domain (p. 315-316).

Recent neurological studies also emphasize the relevance of social interactions in creative processes. The well-known Argentinean neuroscientist Facundo Manes highlights, for example, the importance of social interactions and diverse experiences in the development of creativity "... the sociocultural factor plays a crucial role, since the access to experiences of different nature reshapes the brain connections that are necessary to generate innovative solutions" (Manes, 2014, p. 207).

Creativity might often presuppose solitary activity, but this activity always involves socially constructed meanings, senses and motives. Creativity always develops in interaction with others (even when this interaction is at the level of the symbolic), with social, scientific, artistic and cultural problems and on the basis of the existent resources and knowledge in the community. Creativity is always a distributed process (Glăveanu, 2014a).

Csikszentmihalyi and Sawyer (2014) interviewed creative persons in different fields and explored a relevant moment in the creative process: insights. They observed that the moment of insight appears as one short flash in a complex, time-consuming, fundamentally social process. Insights also depend on interaction with others and social contexts. On the other hand, Hooker, Nakamura and Csikszentmihalyi (2014) highlighted 
the importance of apprenticeship experiences in shaping the potential of young scientists, artists, thinkers, performers and entrepreneurs.

In the field of research on creativity, we see the need to go beyond the idea of solitary experience, beyond studies focused on people's (inner) capacities and expand the focus of analysis to interactions and collaborative creative processes. We also highlight the value of studying creative experiences lived by people and groups (Long, 2014) and of going beyond tests and questionnaires, and adopting qualitative methodologies as an important challenge for researchers in the field of creativity.

More than two decades ago, Montuori and Purser (1995 ) proposed deconstructing the lone genius myth and building a contextual view of creativity. Recently, continuing this line of argument, Eisler, Donnelly and Montuori (2016) have said:

It is our hope that our efforts to outline a gender-holistic, contextual perspective on creativity can make a contribution to this process by pointing to the need to view creativity as embedded in a particular set of social relations. We are well aware that these relations are, at this point in time, still based far too much on dominator dynamics. But we believe that, as creativity becomes more gender-inclusive and contextualized, we have an opportunity to transform not only creativity, but the social and moral web of human relationships in a partnership direction (p. 27).

In short, a social pespective of creativity involves much more than interactions during the creative process. Recognizing the social essence of creativity implies that real and symbolic relationships between groups, genders, powers, artifacts and representations should be the focus of study.

\section{TWO SIDES OF THE SAME COIN: TWO STUDIES, ONE RESULT}

Two different studies that show the same result are presented: creative processes, always depend on interaction among people. The studies have been carried out within the frame of a Doctoral thesis entitled La creatividad en personas comunes. Potencialidades en Contextos cotidianos ${ }^{1}$ (Creativity in ordinary people. Potentials in everyday contexts). Our studies of everyday creativity and on the biographies of creative Argentineans recognized for their achievements in different fields support the understanding of creativity as a sociocultural process that always implies real and symbolic interactions with others and with culturally diverse knowledge, resources and experiences.

\footnotetext{
${ }^{1}$ Doctoral Dissertation presented on March 2011 at Universidad de San Luis (Argentina). In this article an analysis of studies referring to the social character of creative processes is presented. Other analyses were performed; a more complete version is presented in the book: Estudio de Creatividad. Las travesías de Alfonsina, de Astor, de Julios y de Marías. Available at: 


\section{ONE SIDE OF THE COIN OR STUDY 1}

\section{Methods}

In previous research (Elisondo, 2008a; 2008b) we observed relations between the different measures of creativity and people's involvement in extra-curricular and leisure activities. Considering these results, the objective of Study 1 was to analyze motivations, the creative impact and benefits of leisure activities from the perspective of the people involved in them. We interviewed people who participate in structured leisure activities in different artistic, cultural, social and community contexts. 150 adults (between 18 and 85 years old) who live in the Province of Córdoba, Argentina, were interviewed. 73\% of the subjects were females. The people who constituted the study group participated actively and regularly in leisure activities. $21 \%$ of the people participated in NGO carrying out community jobs $(\mathrm{N}=32) .19$ participants practiced classical dance, 18 were dedicated to music and 16 worked on activities related to the visual arts. 16 interviewees worked on handcrafts, 15 participated in religious communities and 9 in theatre workshops. 17\% of those who participated in extra activities did so in several of the artistic and community areas previously mentioned $(\mathrm{N}=25)$. The interviews focused on the following topics: description of extra activities, feelings and motivations associated with involvement in these activities, organization of work, family and leisure schedules, interest in other proposals and leisure activities. We used open, axial and selective coding, the method of constant comparison and theoretical sampling to generate categories and substantive theories (Strauss \& Corbin, 1990).

\section{Results}

We built the following general categories during the analysis of the interviews:

What? Extra activities: leisure opportunities and creativity

When? Time and creativity

Where? Spaces and creativity

With whom? Others and creativity

What? When? Where? With whom? Reconstructions of subjects

In this article we are particularly interested in the category that refers to interactions with others during the creative process. ${ }^{2}$ In the interviews, participants indicated that creativity is always a social process that requires, in a certain way, other people. These people play different roles and occupy different places during the processes of creative development. Classmates, tutors, mentors, families, colleagues, professors, critics, evaluators, coordinators are fundamental in creative processes because they provide, from different points of view, knowledge, support, resources, suggestions, criticism, 
judgements, among other contributions. In the processes of creative development, family and friends have an outstanding role since they support the actions of the participants offering support, help in everyday activities and release them from some responsibilities so that the participants can get involved in the leisure activities they are interested in.

We present excerpts from interviews that show the importance of other people in everyday creativity:

The constant encouragement they give me positively influences my creativity (Lorena, 30 years).

I'm a cop, study psychology at night and do theatre, I could not do anything if not for the support of my children and my husband (Patricia, 40 years).

During involvement in leisure activities, the interactions that ordinary people build with teachers, coordinators, and colleagues, condition the processes of creative development. The exchange of theoretical and practical knowledge, experiences, and ways of performing in these fields broaden the subjects' horizons and enrich their works and creative processes.

Some of the leisure activities in which the interviewees participated imply group constructions (theatre performances, choreographies and circus) in which of necessity, they need to interact with others to build their creative products. These interactions and communications not only influence the creative products themselves but also the processes of creativity development for each of the members of the group.

The public and those who receive the creative products also represent significant others in the creativity development processes of ordinary people. The productions are redefined and reconstructed according to the way others see them and the perceptions of the creator in relation to that view.

We always consider the public presentation of the works, each work is reconstructed in interaction with the public, it is something unfinished that must be completed by the public (Lucas, 23 years).

Some respondents highlighted the social sense of their practices within community contexts, recovering the value of helping others and contributing to society.

I perform various activities, classical dance, play the guitar in a church, I teach the Bible, I help as a volunteer in a little garden, I'm starting vocational guidance with a group in church (...) I have participated in all of these activities, because I like to make my own decisions and to help others, be useful (Laura, 23 years old).

I like learning from each other, with others, being able to help a little and see a smile on the face of others (Florence, 20 years). 
Judges and evaluators also look at the products and influence the creative processes by formulating their opinions and critiques. Others can also generate obstacles and difficulties in creative processes. Some interviewees who participated in group activities expressed the view that certain attitudes and behaviours of their teammates were not favourable towards achieving the intended aims, the fulfillment of tasks and creativity development. Lack of commitment and dedication from some members, difficulties in communication, organization and management of group actions, internal problems among participants are some of the difficulties signalled by the interviewees.

Purpose, time, space and interactions are reconstructed by the participants during the process of deployment of creativity in everyday contexts. Participants build special relations with contexts and other people in order to develop their creative potential through their participation in various cultural, artistic and community activities. Glăveanu and Lubart (2014) found similar results in a study with professionals working in science and creative industries in France. Results showed that social interactions play a key formative, regulatory, motivational and informational role in relation to creative work.

Make time and create spaces for creativity are some expressions that reflect particular constructions of the world oriented by motivations and emotions emerging from the processes of deployment of creativity. Others play an indispensable role in these actions of making time and generating spaces.

\section{THE OTHER SIDE OF THE COIN OR STUDY 2}

\section{Methods}

Study 2 was a case study (Stake, 1995) focused on Big C creativity, i.e., related to prominent figures and socially recognized achievements (Lebuda, 2015). Specifically, we followed the biographical studies of creative personalities (Csikszentmihalyi, 1996; Gardner; 1993; Gruber \& Walace, 1999). The basic criterion for the selection of this group was determined by the social recognition of their work. National and international prizes and distinctions were taken as indicators of this recognition. We counted on the professional advice of specialists in different fields who collaborated on the sample selection. The following creative artists and scientists comprised the study group for this research: Atahualpa Yupanqui, Roberto Arlt, Antonio Berni, Adolfo Bioy Casares, Julio Bocca, Jorge Luis Borges, Julio Cortázar, Enrique Santos Discépolo, Bernardo Houssay, René Favaloro, Roberto Fontanarrosa, Joaquín Salvador Lavado (Quino), Luis Federico Leloir; César Milstein, Victoria Ocampo, Astor Piazzolla, Benito Quinquela Martín, Ernesto Sábato, Alfonsina Storni, Leopoldo Torre Nilsson, Marina Esther Traverso (Niní Marshall), and María Elena Walsh. We developed this study from the analysis of various types of data emerging from: interviews, biographies, autobiographies and documents 
(productions, works, discourses, letters, etc.).

We analyzed each of the cases, using the method of constant comparison and theoretical sampling; taking into consideration interrelationships between subjective and contextual factors (Gruber \& Walace, 1999), we compared the processes developed by creative individuals in order to identify commonly emerging themes (Gardner, 1993) and studied the interrelationships between people, fields and domanis as proposed by Csikszentmihalyi (1996).

\section{Results}

From the biographical study of multiple cases, we built three general sections: Living, Creating and Legacy. The first section, Living, included the following categories of analysis:

Childhood: creativity begins to unfold

Adolescence and youth. Work, contacts and decisions

Adulthood. Create and be recognized

Old age. Create until the end

In the second section, Creating, we defined the following categories:

$1 \%$ : the raw material

99\%: work

Creativity also needs time

Create: alone but accompanied

Create: between abundance and scarcity

Create: between slavery and freedom

Create: between pleasure and pain

Creating is much more than a cognitive process

In the third section, Legacy, we analyzed the contributions of the creative individuals to specific fields and society in general.

As in Study 1, we were particularly interested in categories that refer to interactions with others during the creative process. The biographical analysis carried out shows that in the lives of creative people, interactions with other people (family, professors, friends, colleagues, disciples, etc.) are a conditioning factor for creativity. The relationships with teachers, professors and mentors inside and outside formal educational contexts are a determining factor in the lives of these people. Besides orienting them within the learning of basic knowledge in each field, teachers offer them diverse opportunities, inform them about possibilities (scholarships, contests), help them to form contacts with other people in the field, help them make decisions and find the right path and, most of all, their own path. 
...Pedro Henriquez Urena. To him I owe my first approach to the great authors ( ... ) sitting on a wagon, with a portfolio full of corrected homework (...) I asked: Why, Don Pedro, waste time on those things? And he, with his gentle smile, replied: Because among them may be a future writer (Sabato, 1998, pp. 47-48 ).

With the support of the director of the Clinical Hospital, where he was an intern, Leloir was accepted by Houssay for a doctorate $s$ under his direction (... ) The relationship of Leloir with Houssay lasted unchanged until his death in 1971. ( ... ) After completing his thesis, Houssay advised Leloir to specialize abroad (Leloir In Paladini, 2008, pp. 19-24) .

Pair relationships are especially relevant during adolescence and youth. Groups or associations have a great importance in the lives of young people, in that they participate in diverse groups at different life stages. On numerous occasions, they meet people, who at first sight, would seem to be different from them, but with whom they share artistic, political, ideological, educational interests, etc. The creative person and his/ her peers gather to debate, study, paint and compose, and also work on creative enterprises such as the publication of magazines, the creation of exhibitions and art courses for workers. The search for spaces for the exposition of their ideas and works is one of the main activities of creators and their peers during adolescence and youth.

We talked about everything ... (...) Perhaps there Quinquela, with his loving eyes in the Vuelta de Rocha, has intuited the wonderful colours of all his paintings ... And Riganelli found the miraculous blow to his chisel ... and I, myself, maybe have found there the chord or verse to a song that came after ... (Discépolo. In Galasso, 2004, pp.34-35).

Adulthood is a stage in life in which creators count on more resources to deploy creativity (time, contacts, knowledge and economic resources). The relationships with meaningful others are also very important in this period. Relationships are strengthened and new interactions emerge, students and disciples have an outstanding role in adulthood and in old age. In maturity, creative people start positioning themselves at the other end of areas, i.e., they are no longer to be evaluated, but they are the judges and referees; they stop being students and disciples and become teachers and mentors. In adulthood, the creative start to be part of specialized areas, now it is they who play the role of gatekeepers. Managers are also important in the processes of deployment of creativity because they serve administrative, bureaucratic and economic matters providing creative individualss with time, space and money to dedicate their time fully to creative activities. The managers advise creative people on a central aspect of creativity, the promotion and 
selling of works and products. Critics and detractors also play an important role in creative processes, defying and stimulating creative individuals even more.

The first challenge of Lino Patalano (manager) was to change the stereotypical image of the classical dancer, open markets and make Julio dance as much as possible with the most prestigious companies in the world (Bocca. In Montoya, 2007, pp. 147 ).

In old age, family and friends and people who are in charge of the care and attention of creative individuals are especially relevant. These people help them in diverse ways, some take care of vital issues such as feeding, hygiene and health care. Others collaborate with them on the creative process, writing what they dictate, reading to them, escorting them to meetings, conferences, etc.

Besides the interactions with people who offer help and orientation, we are interested in highlighting relationships of creative co-construction. Some of the creative individuals have worked on collaboration with other people forming duos or creative groups. We stress the role of research teams in the case of scientists and also some creative duos: Borges-Bioy Casares; Torre Nilsson-Silvina Ocampo-Adolfo Bioy Casares, Carol Dunlop-Julio Cortázar, Beatriz Guido-Torre Nilsson. Collaborative work provides opportunities for the exchange of knowledge, ideas, problems and solutions and allows for the correction of mistakes and complementing the strengths and weaknesses of each member of the group.

(With Bioy Casares) When we surrendered to the pleasure of doing Bustos Domecq our attitude was, quite different: we had fun all the time (...) I could not have this pleasure with anyone. We wrote and we laughed a lot (Borges. In Braceli, 1999, pp. 47).

My father and my mother worked jointly and dialectically (...) She put in everything she had to shore up Atahualpa humanly and artistically. (Yupanqui's son. In Piazzolla, Chavero and Rey Fuentes, 2002, pp. 23).

In biographical studies it has been observed that the others offer ideas, resources, support and assessments that condition the creative processes throughout life. Peer groups, friends, teachers, tutors, partners have helped the creative person along the path of creation, providing different indispensable elements for the consolidation of respective scientific and artistic careers. Considering the importance of social interactions in creativity, we did not observe differences between people working in different fields. In all cases, interactions with teachers, mentors, colleagues, disciples and family sharpen creative processes. An interesting line for future research is to analyze the kinds 
of influences of others at different moments in the creative process. Also, it is relevant to carry out comparative studies between scientists' and artists' groups in the future.

\section{FIVE CONSIDERATIONS: THE OTHERS AND THEIR ROLE IN MUNDANE AND HISTORICAL CREATIVITY}

The results and analyses carried out allow us to define at least five general characteristics that account for the social character of creative processes.

1. Others participate in the processes of generation of ideas.

This stage of the creative process seems to be the most individual; however, ideas never emerge in a vacuum, but they depend on socially constructed knowledge, readings from others' perspectives, interactions and dialogues. Experiences lived in different contexts, among them the educational, also broaden the possibilities of generating new ideas. Even though the creator is thinking alone, he always does so in relation to others' thoughts, knowledge, and productions. Therefore, this stage in the creative process is also social and is conditioned by cultural and historical factors (Glăveanu, 2015b).

2. The development of ideas and actions in different contexts always depends on other people who offer their assistance, help and orientation.

The contributions of others vary in nature: emotional support, economic aid, specific orientations in relation to the object of knowledge, facilitating contacts with specialized areas, training opportunities and professional growth. In interviews and biographies it has been observed that the contributions of family, friends, colleagues, mates, critics, mentors, disciples and professors are indispensable in the development of creative processes, both for everyday life and recognised creativity. Affective and cognitive support (Gardner, 1993) and necessary aids (Therivel, 1999) are fundamental for the development of creative processes in any area, field and context.

3. Places also play a fundamental role in creative processes.

In the analysis, it has been observed that certain environments (schools, universities, NGOs, cafés, gatherings) facilitate social interaction among people with different perspectives and promote the development of creative processes. The places that people construct and inhabit throughout their lives and the bonds that generate in them, influence the possibilities of developing creative processes in both mundane and recognised forms of creativity.

4. Creativity sometimes develops in duos or creative groups.

Others play an important role in the collaborative processes of creation of creative products. Others not only support, but also have a fundamental role 
in creation. Ideas and creative products are not the property of one person but they emerge from the interaction of duos or groups. The richness of diverse points of view and the knowledge of the participants defines an interesting context for creativity. Specialists in the field of creativity (Gardner 1993; Chadwick \& Courtivron, 1993; John-Steiner, 2000) have also highlighted the role of creative duos and collaborative work during creative processes.

5. The social character of creativity is also visualized in the stage of evaluation or assessment of creative products.

At this stage, expert judges, audiences, the public and critics provide their appreciation in relation to creative products. These assessments also influence the processes and revision or reformulation of the products. It is important that the creative individuals take this moment of the process into account and are able to persuade others to buy their ideas and products. In this sense, the $6 \mathrm{P}$ model of creativity (Kozbelt, Beghetto \& Runco, 2010), besides the components of person, product, process, environment and potential, highlights the need of persuasion as fundamental for the creative processes. The model of the $5 \mathrm{~A}$, Actor, Action, Artifact, Audience, Affordances, (Glăveanu, 2013) also highlights the importance of others, the audience, in the dynamic, complex and systemic creative processes.

Both creativities, 'big' and 'small', require others to develop and materialize in creative products. From the studies briefly presented here we observe that people construct and reconstruct relationships and interactions which have a direct influence on creative processes generating opportunities but also obstacles and challenges (in some cases, others impede the creative process and recognition of the products). For example, particular contexts, such as dictatorships, have hindered the creative process, since, in many cases, the creators are forced into exile. Paris was the city that hosted most of the creative exiles in the sample studied; in this city they found opportunities to continue creating and showing their work, and to contact other creative individuals. Paris was a shelter and an environment conducive to the development of creativity.

Paris was freedom; freedom with all that that word means (...) We were in a dictatorship where the Church always had something to say, and it was logical to feel pressured from all sides. And in Paris (...) the mentality was different. Not surprisingly, artists were always seeking freedom in Paris. (Walsh, 2008 ${ }^{3}$ )

We are interested in highlighting the dynamism of the relationships people build. These change at different moments in life and according to the stages in the processes of creating. Creators who are socially recognized and those who have not yet achieved

\footnotetext{
${ }^{3}$ Available from: http://www.pagina12.com.ar/diario/suplementos/radar/9-4909-2008-11-02.html.
} 
recognition always need others to sustain their pacts with creativity. The search for others and the construction of favourable relations for creativity is an indispensable requirement for the development of creative processes. In both studies we have observed permanent constructions and reconstructions of bonds with others, motivated by people's desire to create and develop in their particular fields.

\section{FINAL REMARKS}

Through interviews with ordinary people and recognized creative individuals, and the study of their biographies, it is possible to see that other people are necessary for the development of creativity. Besides explicit interactions, in creative processes, bonds with other people mediated by diverse cultural artifacts, are built. The books read, artistic works experienced, conferences attended and experiences had in diverse everyday contexts offer ideas, knowledge and perspectives which are an indispensable part of creative processes. Therefore, creativity is always social. Others, their contributions, ideas and productions are determinant in the creative process and the consolidation of new perspectives and products. Creativity is also a cultural process since histories, artifacts, languages and procedures are built and rebuilt over time in relations between people.

In the field of creativity it is necessary to deepen the sociocultural perspective and study the creative experiences of people in everyday life. Qualitative studies, narratives and participant observations are interesting tools for developing these perspectives in the field of creativity. The inherent complexity of creative processes challenges researchers to develop analytically inclusive frames, without disregarding different development levels among the perspectives (Reiter-Palmon, 2014) and celebrating the advances and singularities of each approach (Tanggaard, 2015).

Glaveanu (2014b) proposes six general ideas to "get out of the box" and develop sociocultural perspectives in the psychology of creativity. The first is formulating bold, surprising and new questions. The second idea is reflecting on the definitions constructed and analysing how these facilitate or limit the possibilities, methodologies and possibilities of analysis and new interpretations. The third idea is broadening the traditional units of analysis, in general centered on the individual, to incorporate perspectives that study the interactions between subjects in particular contexts. The fourth idea is searching for unique interesting samples to develop new methods. The fifth idea refers to the need to build theories and not only quote the developments of other authors. The sixth idea implies thinking through the conclusions of the studies in practical terms, i.e., understanding research about creativity beyond that of a scientific or academic exercise.

Thinking through the results of our research in practical terms, we consider it important to promote interaction with different people and knowledge in formal, non- 
formal and informal educational contexts. Following this idea, we have developed educational experiences with unexpected teachers (by means of inviting teachers to classes, who may be surprising for the students) at university (Elisondo, Donolo \& Rinaudo, 2012; 2013; Elisondo \& Melgar, 2016). Moreover, we believe it is relevant to promote participation in leisure activities and the construction and reconstruction of social spaces for the development of the arts, sciences, sports and community development. In urban contexts it is indispensable to develop policies and actions oriented towards the growth of creative cities that offer multiple and diverse spaces for citizens to expand their creative potential. In the field of creativity research, we highlight the importance of broadening the sources of enquiry and analysis, accounting for the multiplicity of voices, representations, subjects and interactions that are weaved together in creative forms of expression.

\section{REFERENCES}

Braceli, R. (1997) Borges-Bioy. Confesiones, confesiones. (Borges-Bioy. Confessions, confessions). Buenos Aires: Sudamericana.

Csikszentmihalyi, M. (1996) Creatividad. El fluir y la psicología del descubrimiento y la invención. (Creativity. The Psychology of Discovery and Invention). Barcelona: Paidós.

Csikszentmihalyi, M. \& Sawyer, K. (2014). Creative Insight: The Social Dimension of a Solitary Moment (pp 73-98). In Csikszentmihalyi (Comp.) The Systems Model of Creativity. Netherlands: Springer.

Chadwick, W. \& I. Courtivron (1993). Los otros importantes: creatividad y relaciones íntimas. (Significant Others. Creativity \& Intimate Partnership). Madrid: Editorial Catedra.

Eisler, R., Donnelly, G. \& Montuori, A. (2016). Creativity, Society, and Gender: Contextualizing and Redefining Creativity. Interdisciplinary Journal of Partnership Studies, 3(2). Retrieved July 14, 2016, from http://pubs.lib.umn.edu/ijps/vol3/iss2.

Elisondo, R. (2008a). Creatividad en alumnos universitarios. Relaciones entre creatividad y variables académicas, cognitivas $y$ de personalidad. (Creativity in university students. Relations between creativity and academic, cognitive and personality variables). Thesis presented at Murcia University. Unpublished.

Elisondo, R. (2008b). Creatividad y sus contextos. Estudios en la Universidad. (Creativity and contexts. Studies at the University). Master Thesis presented at Río Cuarto University. Unpublished. 
Elisondo, R., Donolo, D. \& Rinaudo, M. (2013). The Unexpected and Education: Curriculums for Creativity. Creative Education, 4(12b). Retrieved June 14, 2016, from http://www.scirp.org/journal/ce/

Elisondo, R. (2013). Potencialidades creativas en contextos cotidianos. (Creative potential in everyday contexts). In D. Donolo \& R. Elisondo (Eds.) Estudio de Creatividad. Las travesías de Alfonsina, de Astor, de Julios y de Marías (Creativity study. Alfonsina, Astor, Julio y Maria's cruises). (pp. 47-390). Tenerife: Sociedad Latinoamericana de Comunicación Social. Retrieved June 24, 2016, from http://www.revistalatinacs.org/067/cuadernos/10CBA.pdf

Elisondo, R. (2015). La creatividad como perspectiva educativa. Cinco ideas para pensar los contextos creativos de enseñanza y aprendizaje. (Creativity as educational perspective. Five ideas to think creative contexts of teaching and learning). Revista Electrónica Actualidades Investigativas en Educación, 15(3), 1-23. Retrieved June 2, 2016, from http://revista.inie.ucr.ac.cr/index.php/aie/article/view/855/913

Elisondo, R., Donolo, D. \& Rinaudo, M. (2012). Docentes inesperados y Creatividad. (Unexpected teachers and Creativity). Revista Electrónica de Investigación Docencia y Creatividad, 1, 103-114.

Elisondo, R. \& Melgar, F. (2016). Las ratas y los estudiantes. El poder de la novedad en la educación. (Rats and students. The power of innovation in education). Congreso Internacional de Ciudades Creativas. Universidad Complutense de Madrid, January 14-16, 2016. Retrieved July 14, 2016, from http://congreso2016.ciudadescreativas.es/Ciudades_Creativas_2016_tomo1.pdf

Galasso, N. (2004). Discepolo y su época. (Discepolo and his time). Buenos Aires: Corregidor.

Garcia, F. (2004). Los ojos. Vida y pasión de Antonio Berni. (The eyes. Life and passion of Antonio Berni). Buenos Aires: Planeta.

Gardner, H. (1993). Mentes creativas. (Creative minds). Barcelona: Paidos.

Glăveanu, V. (2010). Paradigms in the study of creativity: Introducing the perspective of cultural psychology. New ldeas in Psychology, 28(1), 79-93.

Glăveanu, V. (2013). Rewriting the language of creativity: The five A's framework. Review of General Psychology, 17(1), 69-81.

Glăveanu, V. (2014a). Distributed Creativity. Thinking Outside the Box of the Creative Individual. Springer Briefs.

Glăveanu, V. (2014b). The Psychology of Creativity: A Critical Reading. Creativity: Theories-Research-Applications, 1(1), 10-32. 
Glăveanu, V. (2015a). The Status of the Social in Creativity Studies and the Pitfalls of Dichotomic Thinking. Creativity. Theories-Research-Applications, 2(1), 102-119.

Glăveanu, V. P. (2015b). Creativity as a sociocultural act. Journal of Creative Behavior, 49(3), 165-180.

Glăveanu, V. P., \& Lubart, T. (2014). Decentring the creative self: How others make creativity possible in creative professional fields. Creativity and Innovation Management, 23(1), 29-43.

Gruber, H. \& Walace, D. (1999). The case study method and evolving systems approach for understanding unique creative people at work. En R. Sternberg, (Ed.) Handbook of Creativity. Cambridge University Press. New York.

Hennessey, B. \& Amabile, T. (2010). Creativity. Annu. Rev. Psychol, 61, 569-598.

Hoff, E. (2015). She, You and They - More Actors on the Creativity Research Stage! Creativity. Theories-Research-Applications, 2(1), 38-43.

Hooker, C., Nakamura, J. \& Csikszentmihalyi, M. (2014). The Group as Mentor (pp 207-225). In Csikszentmihalyi (Comp.) The Systems Model of Creativity. Netherlands: Springer.

John-Steiner, V. (2000). Creative Collaboration. New York: Oxford University Press.

Kozbelt, A., Begheto, R. \& Runco, M. (2010). Theories of Creativity. In J. Kaufman, R. Sternberg (Eds.) The Cambridge Handbook of Creativity (pp. 447-463). Cambridge: Crambridge Press.

Lebuda, I. (2015). Big C Research - The Big Challenge? Reflections from Research into Eminent Creativity in the Light of the Investment Theory of Creativity Creativity. Theories-Research- Applications, 2(1), 33-45.

Long, H. (2014). An Empirical Review of Research Methodologies and Methods in Creativity Studies (2003-2012). Creativity Research Journal, 26(4), 427-438.

Manes, F. (2014). Usar el cerebro. (Using brain). Buenos Aires: Planeta.

Montoya, A. (2007). La vida en danza. (Life in dance). Buenos Aires: Aguilar.

Montuori A. \& Purser, R. (1995). Deconstructing the Lone Genius Myth: Toward a Contextual View of Creativity. Journal of Humanistic Psychology, 35(3), 69-112.

Paladini, A. (2007). Leloir. Una mente brillante. (Leloir. A brilliant mind). Buenos Aires: Eudeba.

Piazzolla, D., R. Chavero \& Fuentes Rey. G (2002). Astor Atahualpa. Los caminos de la identidad. (Astor Atahualpa. The paths of identity). Retrieved July 14, 2016, from http://www.buenosaires.gob.ar/areas/cultura/cpphc/archivos/libros/astor_atahualpa.pdf 
Reiter-Palmon, R. (2014). Can we Really Have an Integrative Theory of Creativity? The Case of Creative Cognition. Creativity. Theories-Research-Applications, 1(2), 256-260.

Sabato, E. (1998) Antes del fin. (Before the end). Buenos Aires: Planeta.

Sawyer, K. (2006). Explaining creativity: the science of human innovation. New York: Oxford Press.

Stake, R. (1995). The art of case study research. Thousand Oaks, CA: Sage.

Strauss, A. \& Corbin, J. (1990). Basics of Qualitative Research: Grounded Theory Procedures and Techniques. Londres: Sage.

Tanggaard, L. (2015). Reaching Out For Everyday Life Creativity. Creativity. TheoriesResearch- Applications, 2(1), 75-78.

Therivel, W. (1999). Why Mozart and Not Salieri. Creativity Research Journal, 12(1), 67-76.

Corresponding author at: Romina Elisondo 1712 Mariquita Sánchez de Thompson Río Cuarto, Córdoba, Argentina 5800.

E-mail: relisondo@gmail.com 